\title{
A NEW SPECIES OF GENUS GARRA HAMILTON-BUCHANAN (TELEOSTEI: CYPRINIDAE) FROM MANIPUR, INDIA
}

\author{
W. Vishwanath ${ }^{1}$ and H. Joyshree \\ Department of Life Sciences, Manipur University, Canchipur, Manipur 795003, India \\ Email: 1 vnath w@hotmail.com
}

web supplement

\begin{abstract}
A new cyprinid fish species, Garra nambulica is described from the feeder streams of the Nambul River (Chindwin basin) of Manipur, India. The new species has the following combination of characters: head squarish; no proboscis and transverse groove on snout; mental disc length $96.9 \%$ (92.8-102.7) its own width; predorsal scales irregularly arranged, its number 16-29 counted along row adjacent to the midline; chest and belly naked; post pelvic region scaled; gill rakers 10; caudal fin with a $W$-shaped blue black band.

\section{KeYWords \\ Chindwin basin, fish, Garra nambulica sp. nov., India, Manipur, Nambul river}

Small sized, hill stream inhabiting fishes of the genus Garra Hamilton-Buchanan (Cyprinidae: Garrinae) are characterized by the possession of developed suctorial disc on the under surface just behind the mouth. The fishes maintain themselves against swift currents by clinging to the substratum with the help of their disc and the horizontally placed paired fins, especially the pectorals (Menon, 1964). There are some reports on the occurrence of Garra in Manipur and its neighbourhood. The following species have been described from Manipur: $G$. abhoyai and G. naganensis by Hora (1921), G. manipurensis by Vishwanath and Sarojnalini (1988), G. litanensis by Vishwanath (1993), G. compressus by Kosygin and Vishwanath (1998) and G. elongata by Vishwanath and Kosygin (2000). Vishwanath (1993) also recorded G. lissorhynchus, G. rupecula, G. kempi, G. nasuta, G. gravelyi and G. gotyla. Menon (1974) treated G. abhoyai (Hora) as a synonym of G. rupecula (McClelland).

While collecting fresh water fishes of the streams draining to Nambul river, Chindwin basin in Manipur, specimens of Garra which do not fit into the so far described species of the genus have been found and are herein described as Garra nambulica sp. nov.

\section{Materials and Methods}

Measurements and counts followed Menon (1964). Predorsal scales are counted along the row adjacent to the irregularly arranged midline scales. Measurements were made with a dial caliper to the nearest $0.1 \mathrm{~mm}$ and expressed as percentage of standard length (SL) or head length (HL). The type specimens of the new species are deposited in Manipur University Museum of Fishes (MUMF).

\section{Garra nambulica sp. nov.}

(Figs. 1-3)

\section{Material examined}

Holotype: 3.ii.2004, Ireng lok (stream of Nambul river), Singda village,Manipur, India, 58.5mm SL, coll. H. Joyshree, MUMF 8003

Paratypes: 2 exs., same as of holotype, 53.8-76.2mm SL, MUMF 8001-8002; 5 exs. 42.9-61.4mm SL, MUMF 8004-8008; all from Conchak lok (stream of Nambul river), Singda village.

\section{Etymology}

The species is named after the Nambul River, its type locality.

\section{Diagnosis}

Body moderate sized; head squarish; no proboscis and transverse groove on snout; mental disc length $96.9 \%$ (92.8102.7) its own width; predorsal scales 16-29; chest and belly naked; post pelvic region scaled; gill rakers 10; caudal fin with a W-shaped blue black band.

\section{Description}

D. ii, 6; P. i, 12; V. i, 6; A. ii, 4; C. 10+9; L. 1. 34-35; L. tr. 4/1/3. Predorsal scales 16-29. General appearance of the fish is as shown in Figure $1^{\mathrm{w}}$. Body cylindrical and elongated. Head moderately compressed. Snout blunt and squarish, without proboscis and transverse groove. Mental disc well developed, its width almost equal its length and head width. Barbels two pairs, one rostral and one maxillary, both shorter than eye diameter. Dorsal profile straight to slightly convex. Predorsal midline scales arranged unevenly, its number ranging from 19 to 26 , anterior ones minute, gradually becoming larger behind (Fig. $\left.2^{\mathrm{w}}\right)$. Chest and belly naked, post pelvic region with scales (Fig. $3^{\mathrm{w}}$ ). Dorsal fin origin nearer caudal fin base than snout tip. Caudal fin forked. Vent situated slightly nearer to pelvic fin origin than anal fin origin. Gill rakers 10.

Tubercles on snout and opercular region are arranged as follows: one closely spaced horizontal row below nostrils and another widely spaced row of larger tubercles below, running parallel below eyes and nostrils on each side of head. Preopercle has four vertical rows of closely spaced small tubercles. Upper part of snout anterior to interorbital space has two rows of closely spaced small tubercles and interorbital region with some prominent tubercles.

${ }^{w}$ See Figures 1-3 in the web supplement at www.zoosprint.org 
Proportional measurements of holotype and paratype (in parenthesis). Head length $22.4 \%$ (20.5-24.5) SL; head width $64.1 \%$ (56.0-69.5) of head length; head height $62.6 \%$ (55.7-75.8) HL; snout length $30.1 \%$ (28.6-32.9) HL; eye diameter $19.0 \%$ (15.825.2) HL; inter orbital space $50.8 \%$ (46.2-53.9) HL; disc length $96.9 \%$ (92.8-102.7) disc width; body depth $17.7 \%$ (16.4-19.5) SL; predorsal length $50.7 \%$ (47.1-58.3) SL; pectoral length $84.6 \%$ (80.3-91.4) HL; caudal peduncle height $79.9 \%$ (70.7-91.5) its length; distance between ventral and anal fin origins $50.5 \%$ (47.8-54.4) the distance between ventral and caudal fin base. Distance between vent and anal fin origins 38.5\% (34.0-43.4) the distance between ventral and anal fin origins.

\section{Colour in life}

Body yellowish-brown. Fins orange. Two to three rows of scales above lateral line in the anterior half of body tinted with orange. A dark spot at the upper angle of the gill opening. Dorsal fin with broad transverse black bar near the free margin. Caudal fin with a 'W'- shaped blue black band.

\section{Colour in formalin}

Body dark grey. Yellowish-white ventrally.

\section{Discussion}

Menon (1964) grouped Garra's with W-shaped caudal band in lissorhynchus complex. Thus the new species, as it has similar band on caudal fin may also be grouped under lissorhynchus complex for the time being until further phylogenetic studies are done. The species is similar to G. lissorhynchus in having predorsal scale; absence of scales on chest and belly; same number of lateral line scales and gill rakers. However, it differs from the latter in having shallower body, its depth 17.7 (16.419.5) vs 20.7 (20.1-21.7) \% SL; shorter snout, its length 30.1 (28.6-32.9) vs 34.7 (34.2-35.1) \% HL; wider disc, its width 88.3 (83.5-!00) vs 85.9 (80.3-93.6) \% head width (at eye); shorter disc, its length 96.9 (92.8-102.7) vs 101 (96.1-105.0) \% disc width; longer predorsal, its length 50.7 (47.1-58.3) vs 49.4 (46.5-50.7); more predorsal scales, its number (16-29 vs. 11-14); less number of gill rakers 10 vs 12 ; shorter pectoral fin 84.6 (80.3-91.4) vs 91.9 (86.0-98.6); distance of vent to anal fin origin 38.5 (34.0-43.4) vs 34.7 (31.9-39.2) \% distance between pelvic and anal fin origins. The new species also differs from $G$. rupecula in having predorsal scales (vs absent), post-pelvic region scaled (vs absent); shorter disc, its length 96.9 (92.8-102.7) vs 111.9 (97.5-
Table 1. Morphological characters of Garra nambulica sp. nov.

\begin{tabular}{|c|c|c|}
\hline & $\begin{array}{l}\text { Holotype } \\
\text { MUMF } 8003 \\
\mathrm{~N}=1\end{array}$ & $\begin{array}{l}\text { Paratype } \\
\text { MUMF 8001, 02, 04-07 } \\
\mathrm{N}=6\end{array}$ \\
\hline $\begin{array}{l}\text { Standard Length (mm) } \\
\text { In \% of Standard length }\end{array}$ & 68.5 & $42.9-76.2$ \\
\hline Body depth & 16.9 & $17.7(16.4-19.5) \pm 1.4$ \\
\hline Head length & 20.5 & $22.9(20.5-24.8) \pm 1.5$ \\
\hline Body width at dorsal fin origin & 16.2 & $16.2(15.3-16.9) \pm 0.5$ \\
\hline Body width at anal fin origin & 10.9 & $11.3(10.5-12.2) \pm 0.7$ \\
\hline Caudal peduncle length & 13.8 & $15.7(13.8-17.4) \pm 1.2$ \\
\hline Caudal peduncle height & 12.7 & $12.5(11.7-12.9) \pm 0.4$ \\
\hline Dorsal fin base length & 11.6 & $11.6(10.9-12.2) \pm 0.5$ \\
\hline Dorsal fin height & 18.1 & $19.2(17.4-20.4) \pm 1.1$ \\
\hline Predorsal length & 47.1 & $50.7(47.1-58.3) \pm 2.2$ \\
\hline Pectoral fin length & 18.8 & $19.0(17.2-21.0) \pm 1.2$ \\
\hline Pelvic fin length & 14.4 & $16.0(14.4-17.1) \pm 1.2$ \\
\hline In $\%$ of Head length Head width & 79.4 & $75.8(68.9-79.4) \pm 3.4$ \\
\hline Head height at occiput & 75.8 & $62.6(55.7-75.8) \pm 7.7$ \\
\hline Snout length & 32.6 & $30.1(28.6-32.9) \pm 2.4$ \\
\hline Eye diameter & 17.0 & $19.0(15.8-25.2) \pm 3.1$ \\
\hline Interorbital space & 53.9 & $50.8(46.2-53.9) \pm 2.7$ \\
\hline Disc length & 64.5 & $61.0(57.2-64.5) \pm 2.9$ \\
\hline In $\%$ of Head width, Disc width & 91.0 & $82.1(74.6-83.3) \pm 4.6$ \\
\hline In $\%$ of Disc width, Disc length & 89.2 & $98.0(89.2-105.5) \pm 5.4$ \\
\hline $\begin{array}{l}\text { In \% of Caudal peduncle length } \\
\text { Caudal peduncle height }\end{array}$ & 91.5 & $79.9(70.7-91.5) \pm 6.9$ \\
\hline $\begin{array}{c}\text { In \% of space V- caudal fin origins } \\
\text { Space V - A origins }\end{array}$ & 47.8 & $50.5(47.8-54.4) \pm 2.3$ \\
\hline $\begin{array}{c}\text { In \% of space betn. V \& A origins } \\
\text { Space of Vent- A origin }\end{array}$ & 40.2 & $48.5(34.0-43.4) \pm 3.4$ \\
\hline Counts Predorsal scales & 29 & $16-29$ \\
\hline Gill rakers & 10 & 10 \\
\hline Lateral line & 34 & $34-35$ \\
\hline Lateral transverse scale & $4 / 1 / 3$ & $4 / 1 / 3$ \\
\hline Dorsal fin & II, 6 & II, 6 \\
\hline Pectoral fin & $\mathrm{I}, 12$ & $\mathrm{I}, 12$ \\
\hline Pelvic fin & 1,6 & 1,6 \\
\hline Anal fin II, 4 & II, 4 & \\
\hline Caudal fin & 19 & 19 \\
\hline Circumpeduncular scales & 16 & 16 \\
\hline
\end{tabular}

Table 2. Comparison of morphological characters of Garra nambulica sp. nov. with related species

\begin{tabular}{|c|c|c|c|c|c|}
\hline & $\begin{array}{l}\text { Garra nambulica } \\
\text { sp. nov. } \\
\text { MUMF-8001-8008 } \\
\text { N = } 8\end{array}$ & $\begin{array}{l}\text { G. lissorhynchus } \\
\text { MUMF 4163-4166, } \\
8088-8095 \\
\text { N = } 12\end{array}$ & $\begin{array}{l}\text { G. Iissorhynchus } \\
\text { Menon (1964) } \\
\mathrm{N}=33\end{array}$ & $\begin{array}{l}\text { G. rupecula } \\
\text { MUMF 8048-8052 } \\
\text { N=5 }\end{array}$ & $\begin{array}{l}\text { G. rupecula } \\
\text { Menon (1964) } \\
\mathrm{N}=64\end{array}$ \\
\hline $\mathrm{SL}(\mathrm{mm})$ & $42.9-76.2$ & $58.9-71.9$ & $31.5-73.5$ & $53.8-65.0$ & $20.5-55.5$ \\
\hline Body depth as \% of SL & $17.7(16.4-19.5)$ & $20.7(20.1-21.7)$ & $19.7(15.2-22.5)$ & $18.7(18.3-19.1)$ & $17.6(16.2-24.0)$ \\
\hline Snout length as $\%$ of $\mathrm{HL}$ & $30.1(28.6-32.9)$ & $34.7(34.2-35.1)$ & $51.5(48.0-58.4)$ & $27.9(26.0-29.8)$ & \\
\hline Disc width as $\%$ of head width & $82.1(74.6-=83.3)$ & $81.5(78.8-86.0)$ & $62.5(52.0-80.0)$ & $80.7(79.1-82.3)$ & $66.6(55.5-80.0)$ \\
\hline Disc length as $\%$ of disc width & $98.0(89.2-105.5)$ & $91.1(83.7-98.9)$ & $66.6(55.5-83.3)$ & $97.8(95.6-100.0)$ & $68.9(57.1-80.0)$ \\
\hline Predorsal scale & $16-29$ & 14 & $11-14$ & absent & absent \\
\hline Gill rakers & 10 & 12 & $7-8$ & $7-9$ & $7-9$ \\
\hline Scales behind pelvic fins origin & present & present & present & absent & absent \\
\hline
\end{tabular}


159.2) \% disc width; longer predorsal, its length 50.7 (47.1-58.3) vs 49.5 (41.5-53.4); head height 62.6 (55.7-75.8) vs 57.4 (53.963.5); shorter snout, its length 30.1 (28.6-32.9) vs 47.2 (44.250.8); gill rakers (10 vs 7-9); distance between vent and anal fin origins 38.5 (34.0-43.4) vs 34.9 (31.5-41.5) \% distance between pelvic and anal fin origin.

In Garra, shifting of vent forward is considered to be an adaptation to torrential water current and is of systematic significance (Menon, 1964). The present species has more forwardly placed vent than in G. lissorhynchus and G. rupecula; distance between vent and anal fin origins in distance between ventral and anal fin origins 38.5 (34.0-43.4) vs 34.7 (31.9-39.2) and 34.9 (31.5-41.5). The mental disc is also better developed than the two species under comparison, disc width in $\%$ of Head width 88.3 (83.5-100) vs 85.9 (80.3-93.6) and 84.9 (76.394.1). Thus, the fish is probably more adapted towards torrential habit.

Differences have been found between the data of Menon (1964) and present examination of specimens of G. lissorhynchus and G. rupecula collected from Manipur. These variations are mostly on body proportions. In hill streams, fishes face various hardships, i.e., food availability and interspecies competitions. There may be variations in the body proportions depending upon the ecological and physiological conditions of the fish. However, not much variation has been seen in meristic counts and position of vent etc. The observations may be regarded as intraspecific variations.

\section{ReFERENCES}

Hora, S.L. (1921). India cyprinoid fishes belonging to the genus Garra with notes on related species from other countries. Records of the Indian Museum 22: 633-689.

Menon, A.G.K. (1964). Monograph of the cyprinid fishes of the genus Garra Hamilton. Memoirs of the Indian Museum 14(4): 173-260.

Vishwanath, W. (1993). On a collection of fishes of the genus Garra Hamilton from Manipur, India with description of a new species. Journal of Freshwater Biology 5(1): 59-68.

Vishwanath, W. and Ch. Sarojnalini (1988). A new cyprinid fish, Garra manipurensis, from manipur, India. Japanese Journal of Ichthyology 35(2): 124-126.

VIshwanath, W. and L. Kosygin (1998). A new cyprinid fish Garra compressus from Manipur, India. Journal of Freshwater Biology 10(12): 45-48.

Vishwanath, W. and L. Kosygin (2000). Garra elongata, anew species of the family garrinae from Manipur, India (cyprinid, cypriniformes). Journal of the Bombay Natural History Society 97(3): 408-414.

\section{ACKNOWLedGements}

We are thankful to NBFGR (National Bureau of Fish Genetic Resources), Lucknow, for financial assistance through ICAR-NATP.

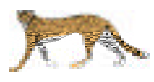

Lunuwila day roost, North Western Province $\left(7^{0} 21^{\prime} \mathrm{N} \& 79^{0} 53{ }^{\prime} \mathrm{E}\right)$ -- located in the intermediate zone this colony was also located in a bungalow and consisted on average only 20 individuals. The bungalow is surrounded by coconut cultivations, home

\section{EVIDENCE OF FISH IN THE DIET OF GREATER FALSE VAMPIRE BAT MEGADERMA LYRA IN SRI LANKA}

\section{M.R.M.P.N. Goonatilake, W.B. Yapa* and W.D. Ratnasooriya}

Department of Zoology, University of Colombo, Colombo 03, Sri Lanka.

Email: * (corresponding author) wipula@zoology.cmb.ac.lk

Being the second largest order of mammals, bats show an array of diverse feeding habits. Although frugivory and insectivory are the commonest forms of diet in majority of the species, some bats are highly specialized in diet viz. sanguinivory (feeding on blood) and picivory (feeding on fish). Fish eating bats are included in the family Noctilionidae (French, 1997), however members of three other families, viz. Vespertilionidae, Megadermatidae and Phlostomidae are also known to feed on fish (Grzimek, 1990). Megadermatids are referred to as typically carnivorous with proven records of fish eating (Advani, 1981), who found upon examination of stomach contents, fish to constitute $10 \%$ of the diet of M. lyra in India. Bates and Harrison (1997) stated that since $M$. lyra is a semi carnivorous species, which feed on many species of invertebrates as well as vertebrates, this is undoubtedly a high proportion for a particular prey category. This could be due to either high availability of fish in the study area, or scarcity of other prey items, or that lyra.

We wanted to examine whether $M$. lyra regularly feeds on fish and if so estimate the proportion of fish in its diet. We studied the diet of $M$. lyra by examining fecal droppings collected from two geographically isolated day roost colonies in Sri Lanka. Both these colonies were single species assemblages, only with the M. lyra. $\left.\& 80^{\circ} 20^{\prime} \mathrm{E}\right)$-- located in the wet zone this roost site was in an old bungalow and consisted of 80-100 individuals. This is one of the largest colonies recorded for this species in Sri Lanka (Yapa et al. 2000). This bungalow is surrounded by a large cultivation of tea, rubber and paddy. Several bats in this colony brought the captured prey to the bungalow and used specific locations as their feeding perches. The faecal pellets were collected randomly in different areas of the bungalow between January 2001 and April 2002. During the entire period of study the house was not occupied (except for brief periods by the researchers).

(C) Zoo Outreach Organisation; www.zoosprint.org Manuscript 1259; Received 15 September 2004; Finally accepted 2 February 2005; Date of publication 21 March 2005 fish constituted a consistent food category in the diet of $M$.

Lawalhena day roost, Baddegama, Southern Province $\left(6^{0} 16^{\prime} \mathrm{N}\right.$ 